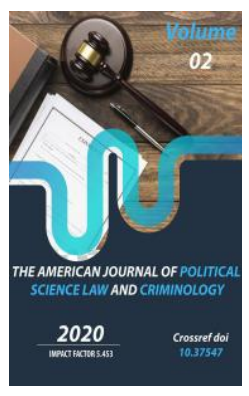

\title{
Inheritance Rights Of Spouses In Case Of Factual (De Facto) Termination Of Marriage
}

Yusupova Oysha Matnazarova

PhD Student Of Tashkent State University Of Law, Uzbekistan

Copyright: Original content from this work may be used under the terms of the creative commons attributes 4.0 licence.

\section{ABSTRACT}

Nowadays, tendencies of marriage and family relations in many foreign countries show that factual family relationships are also obtaining great importance along with official marriage between spouses. This fact, in consequence, is influencing on the couple's rights to inherit. Rapid interstate integration and globalization make it necessary to improve the institute of spouses' inheritance within inheritance law, that is characterized as a conservative sphere of law. The aim of this research is to improve existing inheritance legislation of the Republic of Uzbekistan by defining the criteria for declaring factual termination of matrimony and studying the scope of spouses' rights to inherit in such occasion.

\section{KEYWORDS}

Legal succession, spouse (widow), dissolution of marriage, spouses' rights to inherit, factual termination of matrimony.

\section{INTRODUCTION}

Marriage as a legal category gives a man and a woman the status of a couple and creates rights and obligations between them established by family law. Economical essence of marriage can be seen as a specific financial partnership between spouses.

The purpose of marriage is to create a family. In this sense, if we think of a family and marriage as an integrated whole, then 
marriage should be a necessary and primary part of it. Marriage is designed to ensure survival of generations and to cohabitate with mutual care. Based on the common goals and interests of spouses and cohabitation conditions, a special legal regime is established for the property acquired during marriage and mutual rights and obligations on are imposed spouses.

According to legal scientist Van Erp, norms of inheritance law are strongly influenced by socio-cultural, socio-economic and even religious factors, and it is still considered a local (national or regional) law or even connected to religious law in some legal systems. He emphasizes that strengthening protection of inheritance rights of a living (widowed) spouse and weakening legal protection of children is one of inheritance law's tendencies. As people's life expectancy increases, testator's children are usually grown up when the inheritance case is opened and are able to take care of themselves. For this reason, it is expedient to differentiate the children of the testator on the basis of age, ability to work and need for assistance [1].

Death of a spouse leads to termination of marriage and launch of inheritance process. It should be noted that inclusion of a spouse in the circle of heirs by law is the result of gradual development of inheritance law. Initially, legal succession was carried out only on the basis of kinship, and either husband or wife was not entitled to inherit because they were not related to each other. According to the related scientific literature, even when a living (widowed) spouse was entitled to a share in the inherited property, there was inequality between husband and wife's right to inherit. A wife had more limited inheritance rights than a husband. Men inherited a significant share after the death of his wife, while women, on the contrary, received a negligible share of her husband's inheritance. In the last century, due to codification of inheritance law and amendments to legislation, as well as by establishing the legal status of absolute inheritance in some cases, inheritance rights of men and women have become practically equal [2].

A spouse's right to inherit by law is exercised providing there are no circumstances that prevent (impede) it. They include:

- Declaration of marriage as invalid before or after the opening of succession;

- Recognition as an unworthy heir [3]

- Deprivation of inheritance by order of testator (except for compulsory deprivation of share);

- Dissolution of marriage.

It is known that divorce means termination of marriage between spouses. Termination of marriage as a legal fact leads to the termination of family relationships between husband and wife i.e. to termination of the status of husband or wife. Spouses' right to inherit does not apply to ex-spouse [4].

According to statistics, the number of divorces in the Republic of Uzbekistan in 2019 amounted to 31,389 , of which 19,475 were registered in cities and 11,914 in rural areas [5]. These figures indicate the number of divorces officially registered by Registration of Civil Status Acts (RCSA) bodies. However, there are some cases in our society when family relationships are terminated de facto, but marriages are not officially annulled for some reasons. This may be due to such facts as lack of time, negligence, 
absence of one of the spouses, or the fact that divorce petition has been filed, but one of the spouses has died before the end of the process. In accordance with the current inheritance legislation of the Republic of Uzbekistan, factual termination of matrimony does not have legal consequences.

On October 29, 1994, the Interparliamentary Assembly of the CIS member states adopted Model Civil Code, and in its Article 1181 the following norm was proposed: "If the marriage with the testator is annulled de facto before the opening of inheritance, and it is proved that the couple had lived separately for at least five years before the opening of inheritance, then the court can exclude a spouse from the inheritance by law, except for inheritance on the basis of mandatory share". This norm stipulates the following two conditions for deprivation of an undead spouse from the inheritance:

- De facto termination of marriage before the opening of inheritance;

- Separate living of spouses for at least five years before the opening of inheritance.

This recommendatory norm has been used in the codification of inheritance law in most CIS countries. In particular, this rule is reflected in Article 1150 of the Civil Code of Kyrgyzstan, Article 1070 of the Civil Code of Kazakhstan, Article 1065 of the Civil Code of the Republic of Belarus. The second part of Article 1172 of the Civil Code of the Republic of Tajikistan stipulates this period as three years. Same norm exists in the civil codes of Georgia, Azerbaijan, Turkmenistan and Moldova. [2].

The second part of the previous edition of Article 1143 of the Civil Code of the Republic of
Uzbekistan contained a similar rule stating "If the marriage with the testator is de facto terminated before the opening of inheritance and if it is proved that the couple lived separately for at least five years before the opening of the inheritance, the court decision may exclude the spouse from inheritance legally, but there is an exception where they can get their share in accordance with Article 1142 of the Code." However, this norm was removed in accordance with Law No. 671-II of August, 272004.

To what extent does it comply with principle of social justice if a spouse is still exercising his/her right to inherit in case of de facto termination of marriage and family relationships? Article 14 of the Constitution of the Republic of Uzbekistan states: "The state shall carry out its activities for the benefit of people and society, on the basis of the principles of social justice and the rule of law". Also, Filimonov V.D. stipulates that the essence of the principle of social justice is to solve social contradictions with the use of law" [6].

There are different views in the legal literature regarding deprivation of a spouse of inheritance if marriage is terminated de facto before the opening of inheritance. In particular, such legal scholars as Chipiga T.D. [7], Aslanyan N.P., [8] argued that a spouse should be deprived of the inheritance if there was official marriage but no long-term family relationship, however, V.K. Dronikov [9] and E.B. Eidinova, on the other hand, considered the issue from the opposite point of view [10].

The Family Code of the Republic of Uzbekistan stipulates that a marriage is considered dissolved from the date of registration of 
divorce in a civil status registry office. However, some norms of family law specify legal consequences of de facto termination of marriage. In particular, the fifth part of Article 27 of the Family Code states that in the event of termination of family relations, court may recognize the property acquired by a spouse during their separate life as his or her private property. Thus, deprivation of a spouse's right to inherit in connection with de facto dissolution of marriage does not contradict the norms of family law. On the contrary, removal of a spouse from the list of heirs as a result of de facto termination of marriage is consistent with family law tendencies in every way.

To solve this controversial problem, it is necessary to proceed from the essence of family concept. Though there is no legal concept of family, in theory many authors point out such characteristics of family as cohabitation of spouses, their spiritual and material support, common goals, rights and responsibilities of family members, role of the state in regulation of family relations. Without these characteristics, family would not exist. For example, if a spouse is legally married to one person and has de facto family relationships (actual marriage) with another person at the same time, it indicates that marriage is de facto terminated. Such cases lead to violation of the principles of family law and decrease of social importance of marriage and family. [11, pp. 135-137]

According to Article 1342 of the Civil Code of Georgia (this rule is also stipulated in Article 1503 of the Civil Code of the Republic of Moldova and Article 1159 of the Civil Code of the Republic of Turkmenistan.), if the testator filed a lawsuit against the heir on the grounds of invalid marriage, the widowed spouse loses the right to inherit. In Ukrainian inheritance law, the fact that marriage is declared invalid, rather than its de facto termination, can be the basis for exclusion from inheritance. In particular, according to the fourth paragraph of Article 1224 of the Civil Code of Ukraine, persons whose marriage has been declared invalid or annulled by a court decision are not entitled to inherit one after another.

According to the Civil Code of Spain (Articles 834, 945), in order for the testator's alive spouse to be called to inherit by law, family relationships between them must be both legally and practically (de facto) valid. Legal termination of a family relationship (cohabitation) or establishment of a separate living (Sp. separación legal) occurs in accordance with a court decision, as well as by mutual consent of the couple, certified by a court clerk or notary. Establishment of separate living leads to deprivation of spouses of their right to inherit from each other. Family relationships (cohabitation) can be terminated de facto at the request of one of the spouses or by agreement of both of them without intervention of the relevant authorities (Sp. Separación de hecho). In order to resolve the issue of couple's succession, de facto termination of family relationship is determined in court. Spanish law does not currently set clear criteria for establishing such a fact (but there were legal criteria until 2005) and in each case it is up to the court to determine whether there are sufficient grounds to conclude that the marriage-family relationship is over de facto. At the same time, this fact must be proved by any legal means. The fact that the couple did not live together, that a separate property regime was 
established in respect of the property, that they did not try to reach agreement, and others may be taken as evidence by the court [4].

In France also, de facto termination of marriage between a couple does have legal consequences. It can be grounds for commencement of divorce process (the period of actual separate living before divorce process should be not less than 2 years) [12].

Article 9 of the Civil Code of the Republic of Uzbekistan states that "Exercise of civil rights must not violate rights and legally protected interests of other persons. Participants in civil legal relations are expected to act honestly, rationally and fairly.

The actions of citizens and legal entities aimed at harming another person, abuse of rights in other forms, as well as exercise of law contrary to its purpose are not allowed".

De facto (factual) termination of a marital relationship based on marriage has certain family-legal and civil-legal consequences for spouses. Some legal scholars (Tarusina N.N. and Izmaylov V.V.) argue that "factual divorce" is important for three different types of legal relationships:

1) In determining child's place of residence during the period when the couple lived separately;

2) As a substantiated motive recognized by the court in a divorce process; [2]

3) For the court to establish the property acquired by spouses during their separate life as a private property.
At this point, criteria to determine factual termination of family relationship between spouses are the issue.

According to Article 41 of the Family Code of the Republic of Uzbekistan, if the court finds that it is no longer possible for spouses to live together and maintain family relationships, the court shall divorce them.

In accordance with Paragraph 16 of the Resolution of the Plenum of the Supreme Court of the Republic of Uzbekistan (No. 6 dated from July 20, 2011) "On the practice of law application by courts in divorce proceedings", courts may divorce couples only if they can no longer live together and only if it is found impossible to live as a family because of complete disorientation. A couple's marital relationship can be terminated even if they live together while the status of husband and wife is maintained. In contrast, there are families where the couple has not lived together for a long time, but family and the marital relationship have been preserved. Family law does not specify the obligation of spouses to live together. However, cohabitation of a couple stems from the essence of family and marriage because the purpose of marriage is to build a family, to live together as a couple and have a common household, to ensure continuity of generations. "Factual divorce" means termination of common management of household as one of legal consequences of marriage. When considering divorce cases in court practice, the clearest evidence that a family relationship between a couple has ended is when the couple does not live together. 
Paragraph 5 of Article 27 of the Family Code of the Republic of Uzbekistan stipulates that upon termination of family relations, the court may recognize the property acquired by spouses during their separate life as private property. This norm provides legal consequences of de facto termination of family relationship between the couple. Because when a couple does not live together they do not have the opportunity to jointly own, use and dispose any property acquired at the expense of each other. When they are not living together, they even may not be aware of each other's property. Hence, deprivation of a spouse of the right to inherit in connection with de facto dissolution of marriage does not contradict the essence of the norms of family law. On the contrary, removal of a spouse from the list of heirs as a result of de facto termination of matrimony is consistent with tendencies of family law [11].

Summarizing the above-mentioned facts and arguments, it is proposed to strengthen Paragraph 2 of Article 1143 of the Civil Code of the Republic of Uzbekistan as follows:

"If it is proved that marriage with the testator was annulled in practice as a result of separate living of the couple for at least five years before the opening of inheritance, and both of them entered into family relationships with another person, the court may exclude a spouse from the list of heirs by law."

\section{REFERENCES}

1. Van ERP S. new developments in succession law // Electronic J. of comparative law. - Utrecht, 2010. - Vol. 14, n 2, October.
1) (http://www.ejcl.org/113/article1135.Pdf )

2. Blinkov $\mathrm{OE}$ Inheritance rights of spouses in the member states of the Commonwealth of Independent States and the Baltic States // "Notary". 2006. No. 5. P. 34-38

3. Vershinina E.V., Perevoshchikova A.D. Institute of unworthy heirs in Russia, France and Spain: a comparative legal analysis // Moscow Journal of International Law. 2014. No. 4 (96). S.88-101.

4. Fokina A.D. The surviving spouse's rights under legal inheritance in Russia, France and Spain: a comparative legal analysis. // Moscow Journal of International Law. \# 2. 2018.S. 138-148.

5. Open data / Official site of the State Statistics Committee of the Republic of Uzbekistan. (URL: http: // www.stat.uz)

6. Filimonov V.D. Justice as a principle of law. // State and law. 2009. No. 9. S. 67.

7. Chepiga TD Development of the Soviet system of inheritance in a mature social society. // XXVI Congress of the CPSU and the problems of civil and labor law, civil process. M., 1982.S. 78.

8. Aslanyan N. P. Inheritance of the family members of the testator under Soviet civil law. // abstract of thesis. jurid. sciences. M.: Moscow State University, 1987.S. 6.

9. Dronikov VK History of codification of hereditary legislation of the Ukrainian SSR. // Essays on the history of codification of civil legislation of the Ukrainian SSR: collection of articles Department of Civil Law, KSU. S. 55. 
10. Eidinova E.B. Joint ownership issues in notarial and judicial practice. // Sov. justice. 1977. No. 5.P. 10.

11. Plekhanova OI Inheritance by the surviving spouse with the actual termination of marriage // Glagol of Justice. 2013. No. 1 (5).

12. Vershinina E.V. 2015. Grounds for divorce in Russia and France: a comparative legal analysis. // Moscow Journal of International Law. No. 2 (98). S. 140-149. 